\title{
Estimating Carbon Sequestration of Green Roof Plants in Tropical Climate
}

\author{
Mohamad Norfekry Md. Yacob ${ }^{1}$, Hartini Kasmin ${ }^{1 *}$, Muhammad Iqbal Hakeem \\ Hashim ${ }^{1}$
}

${ }^{1}$ Faculty of Civil Engineering and Built Environment,

Universiti Tun Hussein Onn Malaysia, 86400 Parit Raja, Batu Pahat, Johor, MALAYSIA

*Corresponding Author

DOI: https://doi.org/10.30880/ijie.2021.13.03.024

Received 05 January 2021; Accepted 13 May 2021; Available online 10 June 2021

\begin{abstract}
A green roofs is one of the recommended methods of practice in improving the sustainability of urban areas. Green roofs can be used as a passive technique to reduce carbon dioxide $\left(\mathrm{CO}_{2}\right)$ emissions from the atmosphere. This is due to the role of green roof layers which are vegetation and soil to process the photosynthesis activities and to capture $\mathrm{CO}_{2}$ from the atmosphere. The objective of this paper is to quantify and to compare the amount of $\mathrm{CO}_{2}$ sequestration by ten potential green roof plants, in order to estimate the $\mathrm{CO}_{2}$ reduction within the surrounding atmosphere. It is found that, by planting the Alternanthera Paronychioides (Alternanthera P.) on the roof surface could reduce the indoor air temperature as well as the $\mathrm{CO}_{2}$, thus enhance the quality of air. This study also revealed that the Alternanthera $P$. generates the highest photosynthesis rate or $\mathrm{CO}_{2}$ uptake compared to the other nine plants, as high as $23.59 \mu \mathrm{mol} \mathrm{CO}_{2} \mathrm{~m}^{-2} \mathrm{~s}^{-1}$. It is predicted that if the Alternanthera $P$. is to be installed on a $0.64 \mathrm{~m}^{2}$ test bed roof, the $\mathrm{CO}_{2}$ could be reduced almost 0.010 tonnes, annually. This suggested that by planting Alternanthera $P$. on the roof surfaces may potentially give advantages on mitigating the greenhouse gas emission, particularly $\mathrm{CO}_{2}$, and reducing the impact of global warming.
\end{abstract}

Keywords: $\mathrm{CO}_{2}$ sequestration green roof, global warming

\section{Introduction}

Vegetation layer is the most important factor influencing the green roof performance [1]-[3]. The selection of green roof plants is essential for increase lifetime in urban areas and green roof performance [4]. Recently, some studies have investigated the effects of green roof plant species on carbon sequestration. Truly in absorbing, reflecting and emitting heat, vegetation plays an important role, Agra et al. [5], Charoenkit et al. [6] and Kuronuma et al. [7] capturing the atmospheric carbon by green roof vegetation has been proved. Besides, Agra et al. [5] evaluate the carbon sequestration on green roof vegetation layer. The authors compared each roof to a control roof. They found that carbon dioxide (CO2) concentrations were reduced and capturing higher carbon content in a green roof. In several vegetation and substrate for long term storage and capture of atmospheric carbon can be shown as carbon sequestration [8]. The layers of vegetation and substrate for green roof are the important layers for capture and store atmospheric carbon [9]. Direct system and mechanism of carbon storage in green roof shows in Fig. 1 along with carbon storage for green roof substrate and carbon capture through photosynthesis process by green roof vegetation. Green roof can be applied as a sustainable practice to reduce carbon emission in urban areas [9]-[11] also found that the sedum species was not effective at reducing $\mathrm{CO} 2$ emission at Haifa University, Israel [12]. 


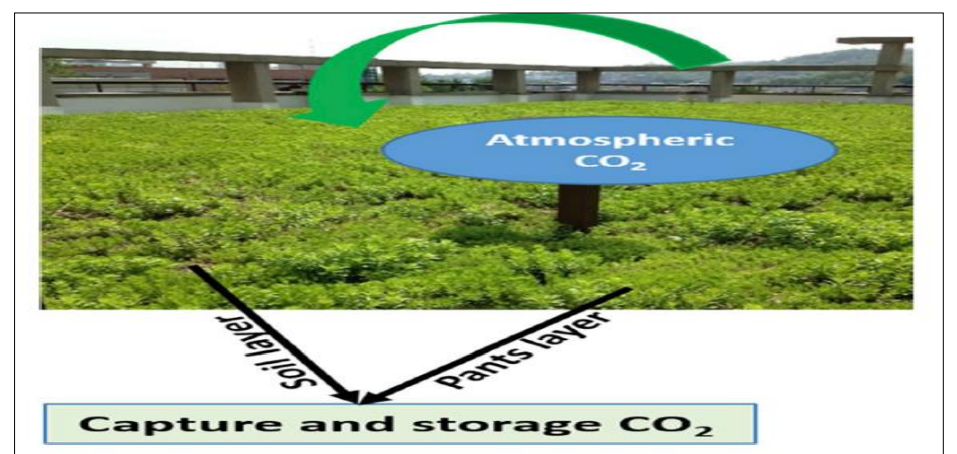

Fig. 1 - Representation of green roofs direct mechanism for $\mathrm{CO}_{2}$ sequestration [10]

Greenhouse gas (GHG) which is the main gas is $\mathrm{CO}_{2}$ contributed to $80 \%$ of global warming [13]. $\mathrm{CO}_{2}$ also has increased faster each year. One of the major contributors in releasing carbon dioxide into atmosphere is from a building [14]-[15]. Planting green roof with incorporating sustainable landscape design is one of promising ways to mitigating GHG [16-17].

Based on the literature studies, green roofs are said to be a useful technique to reduce the $\mathrm{CO}_{2}$ concentration in the atmosphere [18]-[20]. However, studies on evaluating the cooling capacity of green roofs and their contribution in respect of reducing the atmospheric carbon dioxide, especially in the Malaysian climate, are scanty. Therefore, a data collection on $\mathrm{CO}_{2}$ uptake is essential in this study to determine the amount of $\mathrm{CO}_{2}$ that can be taken up by the selected green roof plants in order to minimize the increase in atmospheric $\mathrm{CO}_{2}$. Therefore, this paper will generate information on carbon sequestration data for few selected of local plants suitable for green roof and those with higher $\mathrm{CO}_{2}$ uptakes will be the advantages information for this study.

\section{Material and Method}

\subsection{Experimental Setup and Instruments}

The selection of suitable local plants for the green roof was done at Universiti Tun Hussein Onn Malaysia (UTHM), Batu Pahat, Johor on April 2018. The measurement of $\mathrm{CO}_{2}$ uptake was conducted at Kolej Kemahiran Tinggi Mara Sri Gading (KKTMSG) nearby UTHM because the accessibility of portable photosynthesis machine for 24-hour photosynthesis profile data. The carbon uptakes of ten (10) different types of selected plant were measured using a portable photosynthesis machine, LI-COR 6400. The LI-6400 Portable Photosynthesis System is the instrument used to measure the carbon uptake or net photosynthesis of the plant samples. It is an open gas exchange system, which has a net flow of air through the system.

Three healthy leaves were selected for each plant to measure its photosynthesis rate. Two observations were made for each leaf to monitor its photosynthesis performance. The first observations were made on the upper layer leaves for all plant samples. The second observations were made on the lower layer leaves for all samples to observe their effect to light exposure. Fig. 2 shows on how the measurement of $\mathrm{CO}_{2}$ uptake (photosynthesis rate) was taken.


Fig. 2 - The measurement of $\mathrm{CO}_{2}$ uptakes of plant samples using LI-COR 6400

\subsection{Plants Selection}

Ten types of tropical plant were identified as the suitable plants for the green roof experimental, as listed in Table 1. Those plants were selected based on criteria's such as follows; drought tolerant plant which can withstand the extreme weather condition to be located on top of the roofs without fully attention for watering, bushy or leafy type of plants to ensure that the test roof surface can be fully covered. Suitable leaf sizes also needed therefore it can accommodate the leaf clamp of the photosynthesis machine LICOR LI-6400 Portable Photosynthesis. The plant is based on tropical schrub plant with drought tolerant. 
Table 1 -Type of selected plants

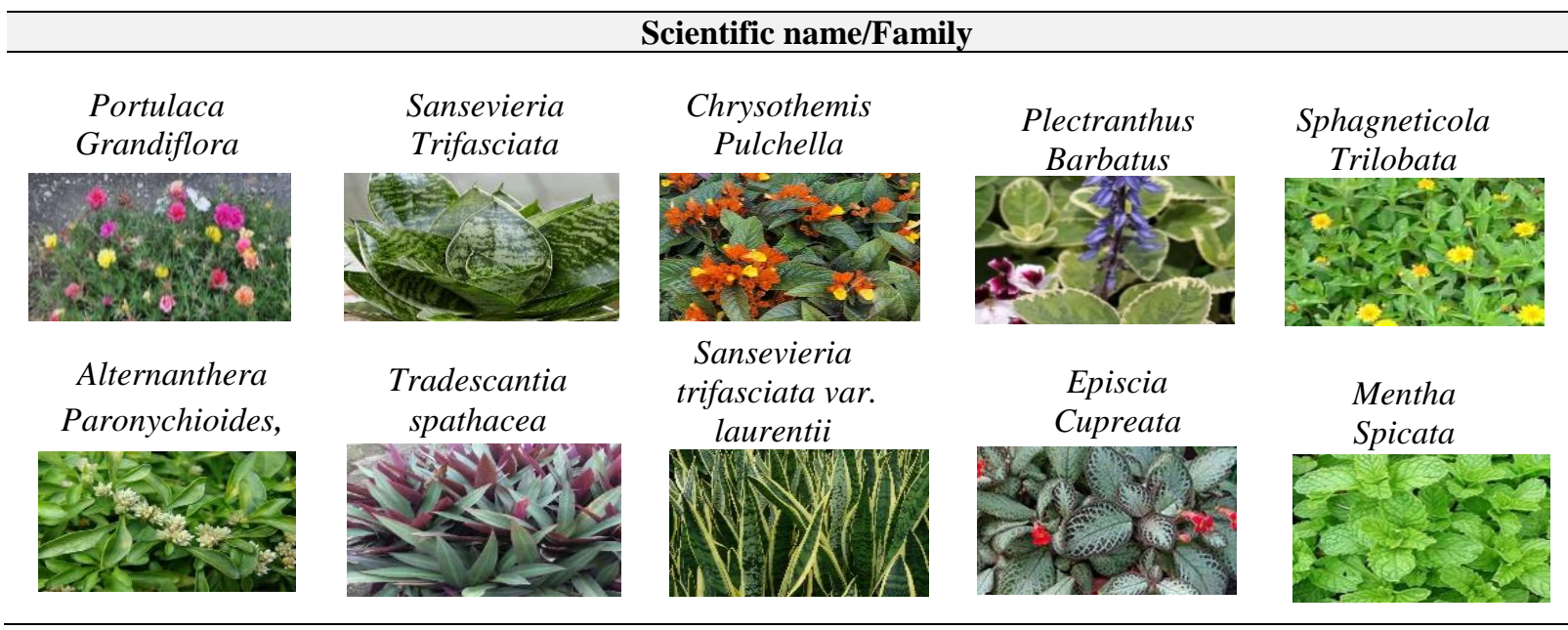

\subsection{The Photosynthesis Rate Measurement of Green Roof Plants}

The measurement of the daily and annual $\mathrm{CO}_{2}$ uptake by the selected plants was conducted to predict their ability to reduce the concentration of atmospheric $\mathrm{CO}_{2}$. By using the portable photosynthesis system, LI-6400, the measurement of photosynthesis rate of selected plants was conducted continuously for 48 hours in April 2018, between 8.00 a.m (23 April 2018) and 8 a.m (25 April 2018). In order to calculate the annual net photosynthesis rate, the average value of April was calculated. To evaluate and calculate the $\mathrm{CO}_{2}$ uptake or net photosynthesis rate in plants, several variables were measured using this system. The measured variables are as follows:

- Photo - Photosynthesis rate, in $\mathrm{mol} \mathrm{CO}_{2} \mathrm{~m}^{-2} \mathrm{~s}^{-1}$

- Cond - Stomatal Conductance, in $\mathrm{mol} \mathrm{m}^{-2} \mathrm{~s}^{-1}$

- $\quad$ TLeaf ${ }^{\circ} \mathrm{C}$-Leaf temperature, in ${ }^{\circ} \mathrm{C}$

- ParIn_m - Photosynthetically Active Radiation (PAR), input, measured by GaAsP sensor, or by silicon photodiode in the artificial light source, in mols $\mathrm{m}^{-2} \mathrm{~s}^{-1}$

- $\mathrm{CO}_{2} \mathrm{R} \_\mathrm{ml}-\mathrm{CO}_{2}$ Concentration in the reference analyser, in mols $\mathrm{mol}^{-1}$

\subsection{The Estimation of $\mathrm{CO}_{2}$ Uptake Amount by Green Roof Plant}

In order to estimate the $\mathrm{CO}_{2}$ uptake by plants, calculation of leaf area of plant samples was done to estimate the net photosynthesis rate performed by the plants. The net photosynthesis rate can be calculated by using Eq. (1), adopted from [21].

$$
A=P_{n}-R
$$

where, $A$ is net photosynthesis rate, $P_{n}$ is daytime photosynthesis rate, and $R$ is dark respiration rate.

Following Eq. (1), daytime photosynthesis rate, and dark respiration rate is measured in order to calculate the daily carbon uptake. To calculate the dark respiration rate, the data is obtained in the early morning and late afternoon, in which the photosynthesis was in negative (-ve) values and the PAR value was at $0 \mathrm{mols} \mathrm{m}^{-2} \mathrm{~s}^{-1}$, were used for the calculation.

After the carbon uptake or photosynthesis rate's measurement for selected leaves were completed, the total leaf area must be measured to calculate the average amount of carbon dioxide that can be uptakes by green plant installed on the small-scale roof. This value was used in the calculation of net photosynthesis rate of green roof plants installed on the small-scale roof. The net photosynthesis rate obtained from the calculation demonstrated the amount of carbon dioxide, which can be up taken by the selected green roof plant. Finally, the prediction of annual $\mathrm{CO}_{2}$ uptake was estimated in order to evaluate the $\mathrm{CO}_{2}$ reduction in the atmosphere. Relationship between variables was also observed using correlation studies.

\section{Results and Discussion}

\subsection{Result of Photosynthesis Rate or $\mathrm{CO}_{2}$ Uptake}

On the first phase, all ten types of local green plants, namely, Portulaca G., Alternanthera P., Sanseviera T., Tradescantia S., Chrysothemis P., Sansevieria TvL., Plectranthus B., Episcia C., Sphagneticola T., and Mentha S. data on photosynthesis rate were estimated between 23 and 25 April 2018. The Alternanthera P. showed the highest photosynthesis rate or CO2 uptake. A summary on the results is shown in Table 2. These results demonstrate that the 
heat resistant of the green plants have the ability to absorb more $\mathrm{CO}_{2}$ by the process of photosynthesis and that Alternanthera $P$. has a greater ability than others in this experiment.

Table 2 - Summary of photosynthesis rate data for the ten plant samples

\begin{tabular}{|c|c|c|c|}
\hline No. & Types of plants & $\begin{array}{c}\text { Mean } \\
\text { Photosynthesis } \\
\left(\mu \mathrm{mol} \mathrm{CO} \mathbf{~ m}^{-2} \mathbf{s}^{-1}\right)\end{array}$ & $\begin{array}{c}\text { Photosynthesis } \\
\text { rate ranking }\end{array}$ \\
\hline 1. & Portulaca Grandiflora & 20.22 & 2 \\
\hline 2. & Alternanthera Paronychioides & 23.59 & 1 \\
\hline 3. & Sansevieria Trifasciata & 8.77 & 7 \\
\hline 4. & Tradescantia spathacea & 7.65 & 9 \\
\hline 5. & Chrysothemis Pulchella & 10.72 & 6 \\
\hline 6. & Sansevieria trifasciata var. laurentii & 12.43 & 5 \\
\hline 7. & Plectranthus Barbatus & 8.21 & 8 \\
\hline 8. & Episcia Cupreata & 14.32 & 4 \\
\hline 9. & Sphagneticola Trilobata & 6.58 & 10 \\
\hline 10. & Mentha Spicata & 19.85 & 3 \\
\hline
\end{tabular}

\subsection{Monitoring Results of the Highest $\mathrm{CO}_{2}$ Uptake by the Green Roof Plants}

The second phase of the experiment was to predict the annual $\mathrm{CO}_{2}$ uptake by the Alternanthera P. that shows the greater ability than the other plants.

\subsubsection{Calculation of Leaf Area for Leaf Samples}

The total area of leaf depends on the type of plants, the ability of plant to grow well and the size of the roof area, to calculate its net photosynthesis rate. Initially, 5 pots of Alternanthera $P$. were used to estimate the photosynthesis rate. The total leaf area for each pot was measured where the total leaf area for 5 pots was $5732.67 \mathrm{~cm}^{2}($ Table 3$)$. Therefore, the average value of Alternanthera $P$. in 1 pot was equal to $1,146.53 \mathrm{~cm}^{2}$.

Table 3 -Total leaf area measured in each pot and average leaf area of Alternanthera $P$. in 1 pot

\begin{tabular}{cc}
\hline Potted bag & Leaf Area $\left(\mathbf{c m}^{\mathbf{2})}\right.$ \\
\hline 1 & 1005.4 \\
2 & 1246.2 \\
3 & 1308.23 \\
4 & 971.45 \\
5 & 1201.39 \\
Average leaf area & 1146.534 \\
\hline
\end{tabular}

\subsubsection{Average Photosynthesis and Dark Respiration Rate for April 2018}

Fig. 3 shows the photosynthesis rate for Alternanthera P. monitored between 23 and 25 April 2018, from 8.00 a.m. until 6.00 p.m. ranges from $1.20 \mu \mathrm{mol} \mathrm{CO} 2 \mathrm{~m}^{-2} \mathrm{~s}^{-1}$ to $23.59 \mu \mathrm{mol} \mathrm{CO}_{2} \mathrm{~m}^{-2} \mathrm{~s}^{-1}$, while on 24 April 2018 , the photosynthesis rate ranges from $1.36 \mu \mathrm{mol} \mathrm{CO} \mathrm{m}^{-2} \mathrm{~s}^{-1}$ to $18.30 \mu \mathrm{mol} \mathrm{CO} \mathrm{Cm}^{-2} \mathrm{~s}^{-1}$. The rate of photosynthesis value for 25 April 2018 is $1.21 \mu \mathrm{mol} \mathrm{CO} \mathrm{m}^{-2} \mathrm{~s}^{-1}$ because of the complete 24-hour cycle is at 8.00 a.m. The negative (-ve) value in the graph represents the dark respiration rate performed by the leaves. On 23 April 2018, the dark respiration range rate of $-0.78 \mu \mathrm{mol} \mathrm{CO} \mathrm{Cm}^{-2} \mathrm{~s}^{-1}$ until $-2.01 \mu \mathrm{mol} \mathrm{CO}_{2} \mathrm{~m}^{-2} \mathrm{~s}^{-1}$ was observed between 8.00 p.m and 12.00 a.m., whereas, on 24 April 2018, the dark respiration rate was observed from 12.00 a.m. until 6.00 a.m, and 8.00 p.m until 12.00 a.m, at a value of $-0.20 \mu \mathrm{mol} \mathrm{CO} \mathrm{m}^{-2} \mathrm{~s}^{-1}$ until $-1.45 \mu \mathrm{mol} \mathrm{CO} \mathrm{m}^{-2} \mathrm{~s}^{-1}$. It also shows that photosynthesis rate was at the higher values during the daytime hours between 10.00 a.m. and 4.00 p.m. After that, it gradually decreased as soon as the solar radiation declined.

\subsubsection{Calculation of Net Photosynthesis Rate ( $\mathrm{CO}_{2}$ Uptake)}

The net photosynthesis rate is calculated following equation (1), where the daytime photosynthesis rate, and dark respiration rate are needed to measure the net photosynthesis rate, or net carbon dioxide uptake. The daytime photosynthesis rate was obtained from the photosynthesis measurement during daytime hours, whereas, the dark respiration rate was obtained from the early morning and late evening, when the solar radiation is absent, or when the PAR value was at $0.00 \mu$ mols $\mathrm{m}^{-2} \mathrm{~s}^{-1}$. 


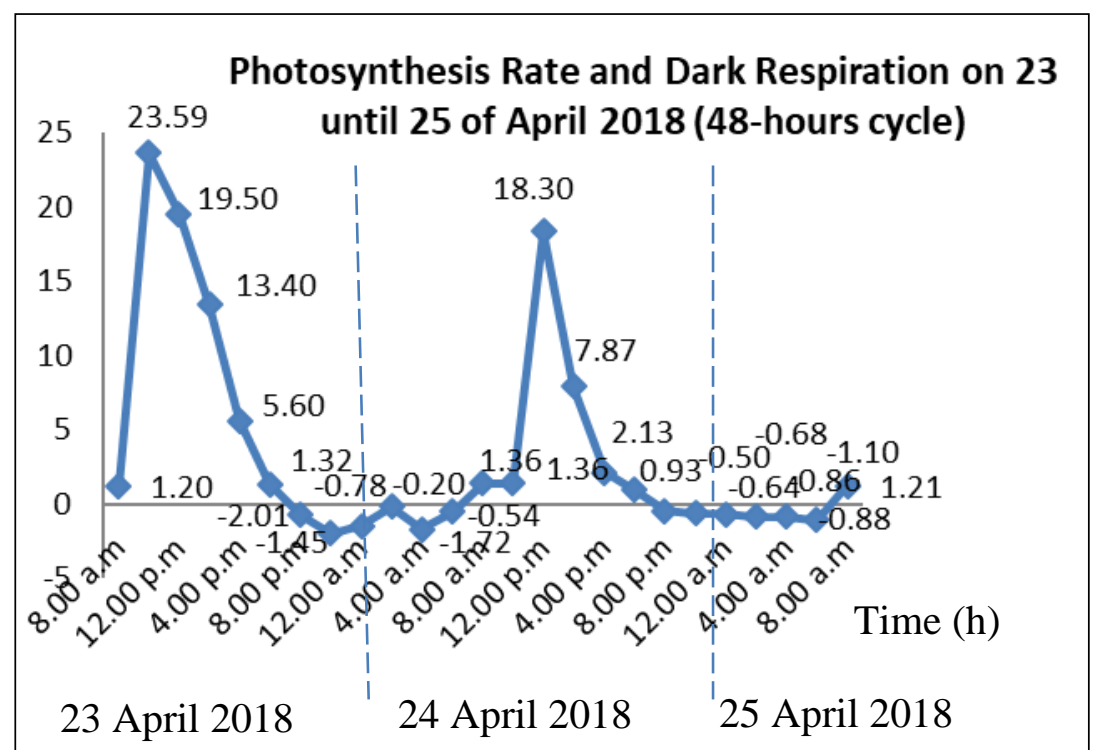

Fig. 3 - Photosynthesis and dark respiration rates for Alternanthera P. between 23 and 25 April 2018

Net Photosynthesis Rate for April 2108

Average 1-day daytime photosynthesis rate for April $2018\left(\mathrm{Pn}_{1}\right)$ :

$\mathrm{Pn}_{1}=\left(10.77 \mu \mathrm{molCO}_{2} \mathrm{~m}^{-2} \mathrm{~s}^{-1}+5.32 \mu \mathrm{molCO}_{2} \mathrm{~m}^{-2} \mathrm{~s}^{-1}\right) / 2$

$=8.05 \mathrm{~mol} \mathrm{CO}_{2} \mathrm{~m}^{-2} \mathrm{~s}^{-1}$

Average 1-day dark respiration rate for April $2018\left(\mathrm{R}_{1}\right)$ :

$\mathrm{R}_{1}=\left(-1.39 \mu \mathrm{mol} \mathrm{CO} \mathrm{m}^{-2} \mathrm{~s}^{-1}\right)+\left(-0.84 \mu \mathrm{mol} \mathrm{CO} \mathrm{CO}^{-2} \mathrm{~s}^{-1}\right) / 2$

$=-1.12 \mathrm{~mol} \mathrm{CO}_{2} \mathrm{~m}^{-2} \mathrm{~s}^{-1}$

Net photosynthesis rate for April $2018\left(\mathrm{~A}_{1}\right)$ :

$\mathrm{A}_{1}=\mathrm{Pn}_{1}-\mathrm{R}_{1}$

$=8.05 \mathrm{~mol} \mathrm{CO}_{2} \mathrm{~m}^{-2} \mathrm{~s}^{-1}-1.12 \mathrm{~mol} \mathrm{CO}_{2} \mathrm{~m}^{-2} \mathrm{~s}^{-1}$

$=6.93 \mathrm{molCO}_{2} \mathrm{~m}^{-2} \mathrm{~s}^{-1}$

Average Annual Net Photosynthesis Rate

In order to calculate the average annual net photosynthesis rate, the average net photosynthesis rate for one pot of Alternanthera Paronychioides for a month was calculated as follows:

Average annual net photosynthesis rate (A):

$\mathrm{A}=\mathrm{A}_{1}=8.05 \mathrm{~mol} \mathrm{CO}_{2} \mathrm{~m}^{-2} \mathrm{~s}^{-1}$

Assuming that 12 hours daylight is received in 1 day $=12 \mathrm{~h} \times 60 \mathrm{~m} \times 60 \mathrm{~s}=43,200 \mathrm{~s}$. Therefore, in one day, one pot of Alternanthera Paronychioides is estimated to uptake:

$8.05 \mathrm{ol} \mathrm{CO}_{2} \mathrm{~m}^{-2} \mathrm{~s}^{-1} \times 0.114653 \mathrm{~m}^{2} \times 43,200 \mathrm{~s}=39,871.73 \mathrm{molCO}_{2}=39.87 \mathrm{mmolCO}_{2}$

In this study, 16 pots of Alternanthera $P$. are needed to be filled on the test bed roof. Therefore, total $\mathrm{CO}_{2}$ uptake $=$ $39.87 \mathrm{mmolCO}_{2} \times 16$ pots $=637.92 \mathrm{mmolCO}_{2}=0.64 \mathrm{~mol} \mathrm{CO}_{2}$.

$1 \mathrm{~mol} \mathrm{CO} 2$ consists of $44.01 \mathrm{~g} \mathrm{CO}_{2}$. Therefore, $0.64 \mathrm{~mol} \mathrm{CO} 2$ consists of $44.01 \times 0.64=28.17 \mathrm{~g} \mathrm{CO}_{2}$. For $6400 \mathrm{~cm}^{2}$ or $0.64 \mathrm{~m}^{2}$ test bed roof could approximately trap almost $28.17 \mathrm{~g} \mathrm{CO}_{2}$ in 1 day.

The annual carbon uptake for 16 pot of Alternanthera $P$. located on test bed roof $=28.17 \mathrm{~g} \times 365$ days $=10282.05 \mathrm{~g}$ $\mathrm{CO}_{2}$ per year $=10.28 \mathrm{~kg} \mathrm{CO}_{2} /$ year $=0.010$ tonnes $\mathrm{CO}_{2} /$ year.

Therefore, 16 pots of Alternanthera P.hioides which installed on $0.64 \mathrm{~m}^{2}$ test bed roof could uptake 0.010 tonnes of $\mathrm{CO}_{2}$ annually. This result can be used to predict the annual amount of $\mathrm{CO}_{2}$ uptake for every single area of roof by using 
the same plants. This situation is really meaningful in fulfilling the Malaysian Government commitment to reduce its carbon emissions up to $40 \%$ by the year 2020 .

\section{Conclusion}

It can be concluded that Alternanthera $P$. could be potentially used as a green roof plant better than the other nine plants since it could sequester more $\mathrm{CO}_{2}$. The annual amount of $\mathrm{CO}_{2}$ uptake from Alternanthera $P$. is predicted to be 0.010 tonnes $\mathrm{CO}_{2}$ /year, could contribute on lessening the $\mathrm{CO}_{2}$ concentration in the atmosphere, thus could serve the Malaysian Government target to reduce its carbon emission up to $40 \%$ by the year 2020. factors: air temperature, leaf temperature, solar radiation available for photosynthesis This study also revealed that the photosynthesis rate or $\mathrm{CO}_{2}$ uptake of Alternanthera $P$. governed by several stomatal conductance are the important variables that influence the photosynthesis rate. Moreover, stomatal conductance is very much influenced by the air temperature and solar radiation intensity.

\section{Acknowledgement}

The authors would like to acknowledge the financial support provided by Universiti Tun Hussein Onn under the Exploratory Research Grant Scheme (ERGS - E052) which made this study possible. The authors would also like to thank the Associate Professor Dr. Alona Cuevas Linatoc, Department of Technology and Natural Resources, Faculty of Applied Science and Technology, Universiti Tun Hussein Onn Pagoh Campus for giving the opportunity to use the instrument for this green roof experiments.

\section{References}

[1] Zhao M., Tabares-Velasco P. C., Srebricm J., Komarneni S. \& Berghage R. (2014). Effects of plant and substrate selection on thermal performance of green roofs during the summer. Building. Environment, 78, 199-211

[2] Raimondo F., Trifilo P., Lo Gullo M. A., Andri S., Savi T. \& Nardini A. (2015). Plant performance on Mediterranean green roofs: Interaction of species-specific hydraulic strategies and substrate water relations. AoB Plants

[3] Young T., Cameron D. D., Sorrill J., Edwards T. and Phoenix G. K. (2014). Importance of different components of green roof substrate on plant growth and physiological performance. Urban for Urban Green, 13, 507-516

[4] Dvorak B. \& Volder A. (2010). Green roof vegetation for North American ecoregions: A literature review. Landscaping. Urban Plan, 96(4), 197-213

[5] Agra H., Klein T., Vasl A., Kadas G. \& Blaustein L. (2017a). Measuring the effect of plant community composition on carbon fixation on green roofs. Urban for Urban Green, 24, 1-4

[6] Charoenkit S. \& Yiemwattana S. (2017). Role of specific plant characteristics on thermal and carbon sequestration properties of living walls in tropical climate. Building. Environment, 115, 67-79

[7] Kuronuma T., Watanabe H., Ishihara T., Kou D., Toushima K., Ando M. \& Shindo S. (2018). CO 2 payoff of extensive green roofs with different vegetation species. Sustainability, 10(7), 2256

[8] Lal R. (2009). Sequestering atmospheric carbon dioxide. Critical Reviews in Plants Science, 28(3), 90-96.

[9] Rowe D. B. (2011). Green roofs as a means of pollution abatement. Environment. Pollution, 159(8-9), 2100-2110

[10] Shafique M., Kim R. \& Rafiq M. (2018). Green roof benefits, opportunities and challenges - a review. Renewable and Sustainable. Energy Reviews, 90, 757-773

[11] Yang J., Yu Q. \& Gong P. (2008). Quantifying air pollution removal by green roofs in Chicago. Atmospheric Environment, 42, 7266-7273

[12] Agra H., Klein T., Vasl A., Shalom H., Kadas G. \& Blaustein L, (2017b). Sedum-dominated green-roofs in a semi- arid region increase carbon dioxide concentrations during the dry season. Science of Total Environment, 584, 1147-1151

[13] Lashof D. A. \& Ahuja D. R. (1990). Relative contributions of greenhouse gas emissions to global warming. Nature, 344(6266), 529-531

[14] Diane Urge-Vorsatz L. D. D. H. \& Mark. D. L. (2007). Mitigation $\mathrm{CO}_{2}$ emissions from energy use in the world's buildings. Building Research and Information, 35(4), 379-398

[15] Santamouris M. (2007). Advances in Passive Cooling. Earthscan, pp. xxvii-xxix

[16] Rahman S. R., Rosley M. S. F., Ahmad H. \& Mohammad S. (2012). Designing a healthy learning environment in the library with extensive green roof. International Technical Conference Proceeding, 3, 52-59

[17] Thani S. K. S. O., Mohamad N. H. N. \& Abdullah S. M. S. (2013). The influence of urban landscape morphology on the temperature distribution of hot-humid urban centre. Procedia-Social and Behavioral Sciences, $85,356-367$

[18] George A. M. (2013). The Potential Carbon Offset Represented by a Green Roof. Bachelor Degree Thesis, University of Virginia 
[19] Chen Y., Mu S., Sun Z., Gang C., Li J., Padarian J., Groisman P., Chen J. \& Li S. (2016). Grassland carbon sequestration ability in China: A new perspective from terrestrial aridity zones. Rangeland Ecology and Management, 69, 84-94

[20] Karlsson Faudot, E. (2018). Potential Carbon Sequestration at Malmo Airport by Use of Extensive Green Roof. Bachelor Degree Thesis, LUND University

[21] Sureeporn K., Jesada L. \& Pojanic K, (2004). Daily and annual $\mathrm{CO}_{2}$ uptake of pterocarpus macrocarpus and azadirachta siamensis under field condition. Kasetsart Journal (Natural Science), 38(3), 419-424 